\title{
Endothelin in the perinatal circulation ${ }^{1}$
}

\author{
Thérèse Perreault and Flavio Coceani
}

\begin{abstract}
During the fetal period, blood is oxygenated through the placenta, and most of the cardiac output bypasses the lung through the ductus arteriosus. At birth, pulmonary vascular resistance falls with the initiation of ventilation. Coincidentally, the ductus arteriosus constricts. Endothelin-1 (ET-1) appears to play an important role during that transition period and postnatally. ET-1 can dramatically increase resistance in the placental microcirculation and may be involved in blood flow redistribution with hypoxia. At birth, the increase in oxygen tension is important in triggering ductus vasoconstriction. It is proposed that oxygen triggers closure of the ductus arteriosus by activating a specific, cytochrome P450-linked reaction, which in turn stimulates the synthesis of ET-1. On the neonatal heart, ET-1 has a positive chronotropic but negative inotropic effect. In the newborn piglet and the fetal lamb, both term and preterm, ET-1 causes a potent, long-lasting pulmonary vasoconstriction. Furthermore, a transient dilator response has been identified, and it is ascribed to nitric oxide formation. ET receptors are abundant in the piglet pulmonary vasculature. They are predominantly of the $\mathrm{ET}_{\mathrm{A}}$ constrictor subtype, though $\mathrm{ET}_{\mathrm{B} 2}$ constrictor receptors may also be present in certain species. The dilator response is linked to the $\mathrm{ET}_{\mathrm{B} 1}$ receptor, and the number of $\mathrm{ET}_{\mathrm{B} 1}$ receptors is reduced in hypoxiainduced pulmonary hypertension. ET-1 appears to be a causative agent in the pathogenesis of hypoxia- and hyperoxiainduced pulmonary hypertension as demonstrated by reversal of hemodynamic and morphological changes with treatment with an $\mathrm{ET}_{\mathrm{A}}$ receptor antagonist. Findings are amenable to practical applications in the management of infants with pulmonary hypertension or requiring persistent patency of the ductus arteriosus.
\end{abstract}

Key words: ductus arteriosus, neonatal pulmonary circulation, neonatal pulmonary hypertension, neonatal cardiomyocytes, fetus.

Résumé : Durant la période fotale, le sang est oxygéné par le placenta et la majeure partie du débit cardiaque courtcircuite le poumon en passant à travers le canal artériel. À la naissance, la résistance vasculaire pulmonaire chute avec le début de la ventilation, et le canal artériel se resserre. L'endothéline-1 (ET-1) semble jouer un rôle important durant la période de transition et après la naissance. Elle peut augmenter considérablement la résistance dans la microcirculation placentaire et pourrait être mise en cause dans la redistribution du débit sanguin avec l'hypoxie. À la naissance, l'augmentation de la tension en oxygène contribue activement à la vasoconstriction du canal artériel. On postule que l'oxygène provoque la fermeture du canal artériel en activant une réaction spécifique liée au cytochrome P450 qui, à son tour, stimule la synthèse de l'ET-1. L'ET-1 a un effet chronotrope positif, mais une effet inotrope négatif sur le cœur néonatal. Chez le porcelet nouveau-né et le fœtus d'agneau, à terme et avant terme, l'ET-1 provoque une vasoconstriction pulmonaire intense de longue durée. Une réponse dilatatrice transitoire, attribuée à la formation de monoxyde d'azote, a aussi été identifiée. Les récepteurs de l'ET abondent dans le système vasculaire pulmonaire du porcelet. La plupart de ces récepteurs appartiennent au sous-type constricteur $\mathrm{ET}_{\mathrm{A}}$, bien qu'on trouve aussi des constricteurs $\mathrm{ET}_{\mathrm{B} 2}$ chez certaines espèces. La réponse dilatatrice est liée au récepteur $\mathrm{ET}_{\mathrm{B} 1}$, et le nombre de récepteurs $\mathrm{ET}_{\mathrm{B} 1}$ est réduit dans l'hypertension pulmonaire induite par l'hypoxie. L'ET-1 semble être un agent causal dans la pathogenèse de l'hypertension pulmonaire induite par l'hypoxie et l'hyperoxie, tel que démontré par le renversement des modifications hémodynamiques et morphologiques par un traitement avec un antagoniste des récepteurs $\mathrm{ET}_{\mathrm{A}}$. Les résultats se prêtent aux applications pratiques dans le traitement des nourrissons souffrant d'hypertension pulmonaire ou nécessitant une persistance du canal artériel.

Mots clés : canal artériel, circulation pulmonaire néonatale, hypertension pulmonaire néonatale, cardiomyocytes néonatals, fœtus.

[Traduit par la Rédaction]

Received 5 December 2001. Published on the NRC Research Press Web site at http://cjpp.nrc.ca on 19 May 2003.

T. Perreault. ${ }^{3}$ Newborn Medicine, Department of Pediatrics, The Montreal Children's Hospital, McGill University, 2300 Tupper Street, Montreal, QC H3H 1P3, Canada.

F. Coceani. Scuola Superiore Sant' Anna, 56127, Pisa, Italy.

${ }^{1}$ This paper has undergone the Journal's usual peer review process.

${ }^{2}$ Corresponding author (e-mail: therese.perreault@muhc.mcgill.ca). 


\section{Introduction}

The fetal circulation prior to birth comprises two circuits operating not entirely in parallel but, at the same time, not being arranged in series. Umbilical vein return from the placenta enters the right atrium via the ductus venosus and the inferior vena cava together, albeit without mixing, with the return from the lower body. The fraction of right atrial blood from the ductus venosus is directed across the foramen ovale to the left atrium, while the remainder flows into the right ventricle. Blood from the left atrium then enters the left ventricle to be pumped predominantly to the head and upper extremities. Through the ductus arteriosus, the right ventricle is responsible for perfusion of the lower body and, more importantly, the placenta. Around the time of birth, dramatic changes take place to prepare the fetus for extrauterine life. At birth, pulmonary vascular resistance falls with the initiation of ventilation and the increase in oxygen tension, and systemic vascular resistance increases with the removal of the low-resistance placenta from the cardiovascular circuit. Coincidentally, the ductus arteriosus constricts and then closes, while closure of the ductus venosus is a slower process taking few days.

\section{Umbilicoplacental circulation}

The low-resistance, umbilicoplacental vascular bed in the near-term fetus is almost maximally dilated under normal conditions. However, the highly muscular umbilical vessels rapidly constrict at birth, with consequent obliteration of their lumen and removal of the placenta from the circulatory system of the neonate. The factors that keep the resistance low before birth as well as the factors that suddenly increase the resistance at birth in this vascular bed are not fully understood. Local and (or) circulating agents are presumably involved, as most of the extra-abdominal umbilical vessels and the placental microcirculation are not innervated (Reilly and Russell 1977). In fetal sheep of 127-128 days of gestation, an infusion of ET-1 can significantly increase mean blood pressure in the aorta, cotyledon artery and vein, and inferior vena cava (Adamson et al. 1996). The umbilical arterial blood flow decreases from $494 \pm 54$ to $180 \pm$ $21 \mathrm{~mL} / \mathrm{min}$ and this is caused by a large increase in total vascular resistance across the umbilicoplacental circulation that is not preceded by any transient initial vasodilatation. Characteristically, umbilical arterial resistance is not significantly affected by ET-1 infusion, while resistance in the umbilical vein tends to increase, but the response is variable. In other words, ET-1 preferentially constricts the cotyledon circulation of the fetal sheep.

Despite the lower placental perfusion, the arterial $\mathrm{pO}_{2}$ or oxygen extraction and oxygen content do not decrease during ET-1 infusion. The absence of a change in arterial oxygenation is accounted for by a significant decrease in fetal whole body oxygen consumption from $4.8 \pm 1.2$ to $2.9 \pm$ $0.8 \mathrm{~mL} \cdot \mathrm{min}^{-1} \cdot \mathrm{kg}^{-1}$. The mechanism by which ET-1 affects fetal whole body oxygen consumption is unknown. Nevertheless, it must be appreciated that some physiological responses coincide with a dramatic reduction in whole body oxygen consumption. For instance, the diving response may show a decrease in oxygen consumption reaching $40 \%$ of that resulting from ET-1 infusion. During long dives in seals, oxygen consumption can further decrease to about half the value seen with a short dive, and heart rate decreases dramatically. The mechanism responsible for the lower oxygen consumption during long dives in seals remains under study, but ET-1 could be involved, possibly through an action on the brain and (or) the endocrine system.

The rise in aortic blood pressure during ET-1 infusion is accompanied by a marked decrease in fetal heart rate. This decrease may be mediated partly by a baroreceptor reflex and partly by constriction of the coronary circulation. Furthermore, a significant increase in hemoglobin concentration occurs during ET-1 infusion. This hemoconcentration could result from an increase in fetal secretion of atrial natriuretic peptide (Cheung 1994) and (or) by a shift of fluid from the intravascular to the extravascular space because of the rise in blood pressure or an increased vascular permeability. Vascular impedance is significantly increased without altering the umbilical artery radius as arterial vascular resistance does not change significantly. Accordingly, ET-1 could enhance umbilical arterial stiffness without constricting the vessel. This may have to do with the orientation of the smooth muscle cells in this vessel wall.

All of the above effects are noted with ET-1 blood levels that appear to exceed the physiological range. However, knowing that ET-1 acts in a paracrine manner and that its levels must by inference be higher in tissues than in blood, it is an open question whether the tissue content of ET-1 attained in the experiments is actually much different from that occurring with pathological states.

\section{Ductus arteriosus}

The ductus arteriosus is a large muscular shunt in the fetus, connecting the pulmonary artery with the aorta and allowing blood to bypass the unexpanded lungs. At birth, as the lungs acquire their ventilatory function and blood $\mathrm{pO}_{2}$ rises to extrauterine values, the ductus constricts and within hours undergoes functional closure. Closure of the ductus arteriosus is a major event marking the normal transition from fetal to neonatal life. Since the discovery that closure of the ductus arteriosus at birth is causally linked to the rise in blood oxygen tension consequent to the onset of ventilation, there has been a search for the agent mediating the action of oxygen on ductal muscle. Several vasoactive compounds have been considered through the years, but none of them could satisfy the necessary requirements. A series of investigations by Coceani and his associates has suggested that ET-1 may be a messenger for oxygen. ET-1 is a potent constrictor of the ductus arteriosus (Coceani et al. 1989) (Fig. 1). Furthermore, oxygen like ET-1 causes a slow contraction of the ductus, though the former differs from the latter in showing a more easily reversible effect. In most blood vessels, endothelial cells are the major, if not the exclusive, source of ET-1 (Yanagisawa et al. 1988). However, the ductus arteriosus is an exception in that its synthetic activity is not limited to the endothelium and has been found in the medial layer (Coceani and Kelsey 1991). This accords with the observation that the ductus may contract to oxygen in the absence of the endothelium. In favour of a role of ET-1 in the oxygen-dependent contraction of the ductus are the following additional facts: $(i)$ the rate of ET- 1 release increases 
Fig. 1. Dose-response curve for endothelin in the ductus arteriosus from mature fetal lamb. $P_{\mathrm{O} 2}$ of the medium was 18-24 Torr ( 1 Torr $=101325 / 760 \mathrm{~Pa})$. Each point applies to 16 preparations, except for tests with the $3.5 \times 10^{-9} \mathrm{M}$ and $7 \times 10^{-9} \mathrm{M}$ doses, which were carried out in 8 preparations. In this and Fig. 2, doses are molar concentrations in the bath fluid. Reproduced from Coceani et al. (1989) with kind permission from the National Research Council of Canada.

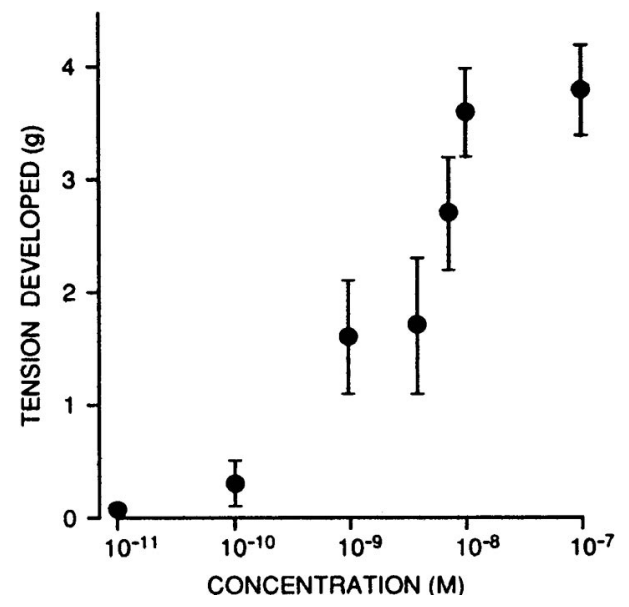

with oxygen concentration (Fig. 2) (Coceani et al. 1992; Coceani and Kelsey 2000), (ii) at low oxygen concentration ( $2.5 \%)$, the endothelin-1 converting enzyme (ECE) inhibitor phosphoramidon has a modest relaxing effect on basal tone (Coceani et al. 1992), (iii) phosphoramidon interferes with the contraction of the ductus at a submaximal oxygen concentration (30\%) and completely inhibits big ET-1 contraction (Coceani et al. 1992), and (iv) BQ-123 markedly inhibits the contraction following exposure to oxygen increase (Coceani et al. 1992). However, at a maximal oxygen concentration, the ductus contraction is not changed by phosphoramidon. It is possible that extreme activation may either overcome the effect of the inhibitor or could involve preferentially a phosphoramidon-insensitive ECE. Collectively, these data implicate ET-1 as the effector agent for oxygen in the ductus and, by extension, assign to this peptide a critical role in the closure of the vessel at birth.

Previous work by Coceani (1994) has also shown that a cytochrome P450 system located in the sarcolemma is crucial for the contractile response of the vessel to oxygen. In fact, treatment with a $\mathrm{CO}$ mixture, to inhibit cytochrome P450, interferes with ET-1 release from the intact and endothelium-denuded ductus preparations (Coceani and Kelsey 2000). Similarly, 1-aminobenzotriazole (ABT), a suicidal substrate for cytochrome-P450-based monooxygenase reactions, lessens the release of ET-1 from the ductus (Coceani et al. 1996b). It is therefore proposed that oxygen triggers closure of the ductus arteriosus at birth by activating a specific, cytochrome P450-linked reaction, which, in turn, yields a hitherto undefined signal for the synthesis of the constrictor ET-1.

To further confirm the postulated function of ET-1 in ductus closure, mice strains have been used with the targeted deletion of a distinct component of the ET-1 system (i.e., the $\mathrm{ET}_{\mathrm{A}}$ receptor subtype). The behavior of the ductus, specifi-
Fig. 2. Endothelin-1 (ET-1) release from the whole ductus arteriosus of fetal lambs at different oxygen concentrations of the medium. ET-1 values are corrected for the wet weight of the tissue. In this and the following figures, the number of tissues is given above each column. Reproduced from Coceani et al. (1992) with kind permission from the National Research Council of Canada.

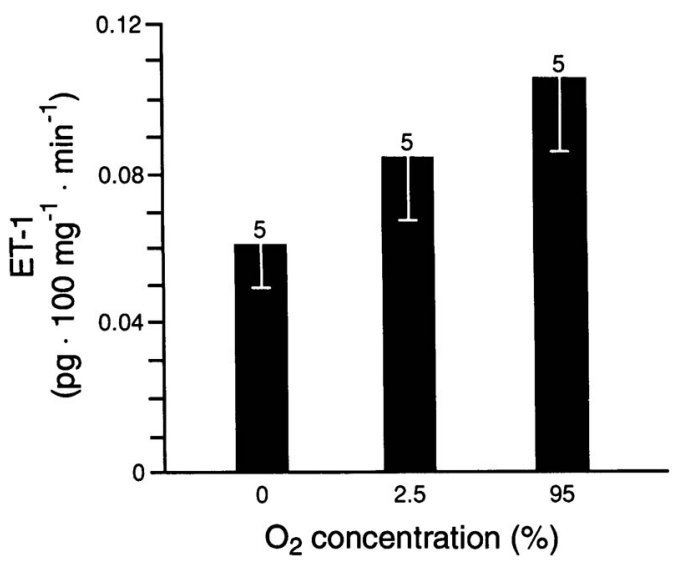

cally its closure, was assessed in vivo and in vitro in $\mathrm{ET}_{\mathrm{A}}$ $-/-,+/-$, and +/+ genotypes (Coceani et al. 1999). To overcome the impact in the $\mathrm{ET}_{\mathrm{A}}$ null mutant of craniofacial anomalies precluding respiratory function and, hence, survival after birth, mice were tracheostomized immediately after cesarean delivery. In the isolated ductus arteriosus from wild-type mice, ET-1 elicits a dual response, consisting of a modest relaxation and a progressively greater contraction with increasing concentrations. No ET-1-induced relaxation is seen in ductus preparations pretreated with BQ-788, confirming that relaxation is due to the presence of $\mathrm{ET}_{\mathrm{B}}$ receptors. The $\mathrm{ET}_{\mathrm{A}}-/-$ ductus contracts marginally to ET-1 $(100 \mathrm{nM})$. Most important is the fact that the tonic contraction to oxygen is nearly absent in the $\mathrm{ET}_{\mathrm{A}}$ null mutant (Fig. 3) and intermediate in the heterozygous mice, hence pointing to an $\mathrm{ET}_{\mathrm{A}}$ gene-dosage effect. In addition, the functional loss is not accompanied by any obvious structural change in the vessel wall. One may therefore conclude that ET-1 is a critical link in the sequence of events being triggered by oxygen and leading to contraction of smooth muscle cells. Still, the ductus from $\mathrm{ET}_{\mathrm{A}}$ null mutants closes normally at birth, and the finding would appear to argue against the function being assigned to ET-1. This apparent inconsistency has been resolved by assuming, on the basis of experimental and clinical data, that postnatal closure of the ductus results from the concurrence of two synergistic processes, promotion of ET-1 function by oxygen and loss of the relaxing influence of prostaglandin $\mathrm{E}_{2}\left(\mathrm{PGE}_{2}\right)$. The relative importance of these processes may vary depending on the species and the particular pathophysiological situation. In fact, in the case of the rat, ET-1 inhibition prevents both oxygen constriction and postnatal closure of the ductus (Taniguchi et al. 2001). In addition, the ductus may close, albeit more slowly, in cyanotic infants (i.e., a condition in which the ET-1 system appears not to be operative (see Coceani et al. 1996a)), and closure is consequently ascribed to the removal of a relaxing influence. Lastly, it must be pointed out that ductus closure has also been connected with the inhibition of voltage-gated potassium channels by oxy- 
Fig. 3. Effect of $\mathrm{O}_{2}$ on isolated ductus arteriosus from $129 / \mathrm{SvEv}\left(\mathrm{ET}_{\mathrm{A}}\right.$-deficient) full-term fetus. (A) $\mathrm{ET}_{\mathrm{A}}-/-\mathrm{ductus}(n=6)$; note 1 preparation showed an exceptionally strong contraction at $95 \% \mathrm{O}_{2}(0.5 \mathrm{mN} / \mathrm{mm})$, thus explaining wide scatter. (B) ET $\mathrm{A}+/-\mathrm{ductus}$ $(n=8)$; not included in group is a preparation with a large relaxation to $\mathrm{O}_{2}$ (loss of tension: $0.16,0.21$, and $0.42 \mathrm{mN} / \mathrm{mm}$ with 12.5 , 30, and $95 \% \mathrm{O}_{2}$, respectively). (C) $\mathrm{ET}_{\mathrm{A}}+/+$ ductus $(n=6)$. (D) Tracings with response of $\mathrm{ET}_{\mathrm{A}}-/-$ ductus (top) and $\mathrm{ET}_{\mathrm{A}}+/+($ bottom) to $30 \% \mathrm{O}_{2}$ (between arrows; baseline at $2.5 \% \mathrm{O}_{2}$ ). Scale bar indicates $10 \mathrm{~min}$. Note that tonic contraction of wild-type ductus to $\mathrm{O}_{2}$ had consistently phasic contractions superimposed whose amplitude increased with $\mathrm{O}_{2}$ concentration. Transient contractions were not included in computation of response; hence, values in panel $\mathrm{C}$ are an underestimate of actual tension generated by preparation. $*, P<$ 0.05 relative to baseline at $2.5 \% \mathrm{O}_{2}$; **, $P<0.01$ relative to baseline at $2.5 \% \mathrm{O}_{2}$. Reproduced from Coceani et al. (1999) with kind permission from the American Physiological Society.

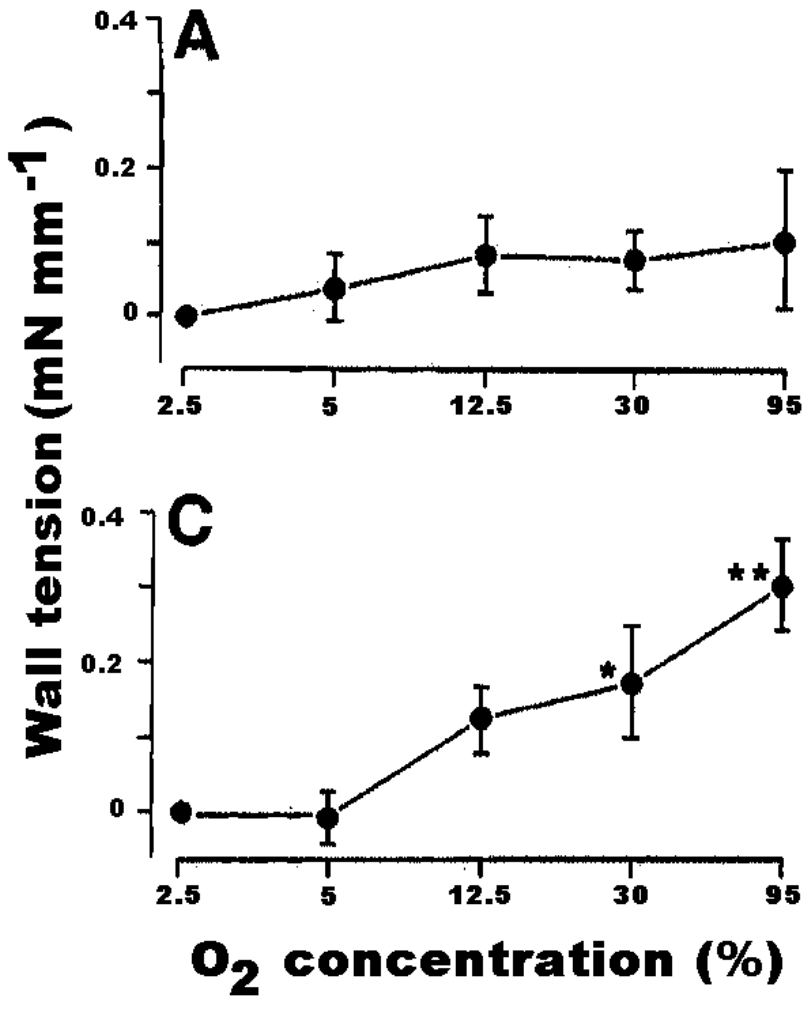

gen (Reeve et al. 2001), and the importance of this mechanism vis-à-vis the ET-1 mechanism remains to be ascertained.

Premature neonates are particularly at risk for infection and sepsis is often associated with reopening of the ductus. While activation of agents with a direct relaxing effect (i.e., $\mathrm{PGE}_{2}, \mathrm{NO}, \mathrm{CO}$ ) is a possibility in this situation, the fact that pyrogens reduce ET-1 release in the fetal lamb ductus (Coceani and Kelsey 2000) cannot be overlooked. This action by pyrogens does not appear to involve endogenous $\mathrm{CO}$ and NO or a modification in cyclic GMP levels, but rather it is linked to an inhibitory effect of $\mathrm{PGE}_{2}$ on ET-1 formation (Coceani and Kelsey 2000).

\section{Ductus venosus}

The ductus venosus is a normal shunt in the fetus that connects the portal sinus with the inferior vena cava and allows a large proportion $(-50 \%)$ of the umbilical vein blood to bypass the liver and rapidly reach the central circulation. By laminar streaming within the inferior vena cava, ductal blood is directed primarily to brain and heart, hence ensuring preferential oxygenation of those organs. After birth, as the umbilical circulation ceases to exist, the ductus undergoes spontaneous closure but, with the timing of the process
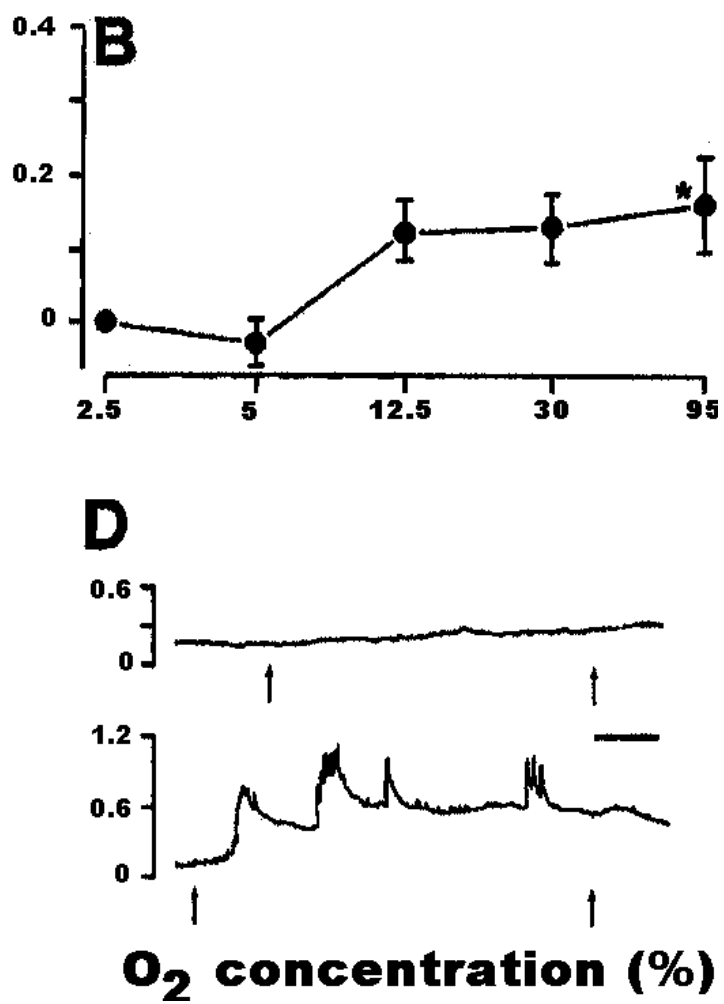

being variable, the vessel may function temporarily as a portocaval shunt. Considerable debate has taken place through the years on the nature of the mechanism controlling this shunt, but sufficient evidence has now accrued, both in vivo and in vitro, pointing to the existence of an active regulation (Adeagbo et al. 1982, 1985, 1990; Kiserud et al. 2000). A prostaglandin, specifically $\mathrm{PGI}_{2}$, is assigned a role in prenatal patency. Conversely, thromboxane $\mathrm{A}_{2}$ and ET-1 (Coceani, unpublished data) are potent constrictors and qualify as effectors for postnatal closure.

\section{Cardiomyoc ytes}

In neonatal rat cells, ET-1 increases cytosolic free calcium $\left(\left[\mathrm{Ca}^{2+}\right]_{\mathrm{i}}\right)$ and spike frequency, and this action is indicative of a positive chronotropic effect (Touyz et al. 1995). Concomitantly, the peptide diminishes $\left[\mathrm{Ca}^{2+}\right]_{\mathrm{i}}$ amplitude in the same cells and, hence, exerts a negative inotropic effect. BQ-123 inhibits both responses, thus pointing to the $\mathrm{ET}_{\mathrm{A}}$ receptor subtype as the main target for ET-1 in neonatal cardiomyocytes. Consistent with this conclusion is the finding that BQ-123 displaces iodinated ET-1 by approximately $85 \%$ against a $15 \%$ value with sarafotoxin S6c. 
ET-1 is known to activate phospholipase C (PLC) and to increase $\left[\mathrm{Ca}^{2+}\right]_{\mathrm{i}}$. It is therefore capable of promoting vascular smooth muscle cell and cardiomyocyte hypertrophy. In neonatal rat myocytes (Xu et al. 1999), ET-1 increases protein and RNA synthesis, but fails to affect DNA synthesis, suggesting that it acts at the transcriptional level. Furthermore, the fact that the peptide does not significantly affect cell number or $\left[{ }^{3} \mathrm{H}\right]$ thymidine incorporation is consistent with myocyte hypertrophy. ET-1 elicits a concentrationdependent increase in $\left[\mathrm{Ca}^{2+}\right]_{\mathrm{i}}$ above basal levels which is not susceptible to ryanodine inhibition. The conclusion is that ET-1 increases $\left[\mathrm{Ca}^{2+}\right]_{\mathrm{i}}$ in neonatal rat cardiomyocytes by releasing $\mathrm{Ca}^{2+}$ from ryanodine-insensitive intracellular pools.

\section{Mesenteric circulation}

In preeclampsia, reduced placental transport of oxygen and nutrients results in fetal hypoxia and often growth retardation. Clinical and animal studies suggest that an hypoxic fetus attempts to preserve cerebral perfusion at the expense of visceral perfusion (Block et al. 1984). It is also thought that blood flow redistribution may be important in the pathogenesis of necrotising enterocolitis, a condition often encountered in growth retarded newborns. In fact, hypoxia has been shown to directly stimulate ET-1 secretion from the rat mesenteric artery in vitro (Rakugi et al. 1990). ET-1, which is intrinsically a more effective mesenteric vasoconstrictor in the newborn than the adult (Nankervis and Novicki 2000; Nankervis et al. 2001), may therefore have a pathophysiological role in hypoxic-ischemic insults, specifically as a precipitating factor in the development of necrotising enterocolitis. A prospective study done in preterm neonates of mothers with preeclampsia has shown that fetal hypoxia increases circulating ET-1 and reduces superior mesenteric blood (SMA) blood flow velocity (Weir et al. 1999). This reduction in SMA blood flow velocity is inversely related to plasma ET-1 concentration. Further studies will have to be done to determine whether ET-1 production or clearance is altered in preeclampsia.

\section{Central nervous system}

Control of cerebral blood flow is particularly important during the neonatal period. The cerebral vessels of the newborn respond to hypoxia and hypercapnia by dilatation (Pryds et al. 1990). However, in the human infant following perinatal asphyxia, this response is abolished or attenuated (Pryds et al. 1990). In a study done using 0- to 5-day-old piglets, ET-1 was shown to block the vasodilatory response to hypoxia and hypercapnia (Aranda et al. 1992). The authors speculate that that $\mathrm{Na}^{+}-\mathrm{K}^{+}$pump and the $\mathrm{Na}^{+}-\mathrm{K}^{+}-\mathrm{Cl}^{-}$ cotransport system may be involved.

Human microglia constitutively express receptors for ET-1. In microglial cultures from human fetal brain tissue (1220 weeks gestation), transient increases in $\left[\mathrm{Ca}^{2+}\right]_{\mathrm{i}}$ are evident with application of either ET-1 or ET-3 suggesting that responses are mediated by the $\mathrm{ET}_{\mathrm{B}}$ receptor since $\mathrm{ET}_{\mathrm{A}}$ receptors respond only to ET-1 (McLarnon et al. 1999). The role for $\mathrm{ET}_{\mathrm{B}}$ receptors in mediating the functions of human microglia remains speculative. It is noteworthy, however, that both astrocytes and endothelial cells, which comprise ele- ments of the blood brain barrier, produce ET-1. ET-1, formed within the endothelial cells of the neonate, may exerts a potent constrictor action by itself or may make the central vessels more susceptible to other spasmogens (Yakubu and Leffler 1999, 2000). Hence, it is likely to play an important role in cerebrovascular homeostasis under normal and pathological conditions.

\section{Pulmonary circulation}

\section{Effects of ET-1}

In the newborn piglet (Perreault and De Marte 1991) and the fetal lamb, both term (Wang and Coceani 1992) and preterm (Liu et al. 2000), ET-1 causes a potent, long-lasting pulmonary vasoconstriction. On a molar basis, the constrictor response to ET-1 is comparable to that of the endoperoxide analog U-46619 (Perreault and De Marte 1991). ET-1 contracts fetal pulmonary resistance arteries and veins in a concentration-dependent manner, the threshold being lower with the veins (1-10 versus $10-100 \mathrm{pM}$ ) (Wang and Coceani 1992). This is in accordance with the work of Ivy et al. (1996), where interference with ET-1 function in the fetal lamb led to a decrease in pulmonary vascular resistance. When basal tone is raised with a thromboxane analog, a dilator response to ET-1 is identified in the isolated lung from newborn piglet (Perreault and De Marte 1991), while in the fetal lamb, it was seen only in pulmonary veins (Wang and Coceani 1992). The lack of dilator response in fetal lamb pulmonary arteries was later confirmed in endothelium-denuded vessels (Wang et al. 1994). In the piglet, the dilator response is ascribed to NO formation, as evidenced by its inhibition following $N^{\mathrm{G}}$-nitro-L-arginine treatment. It does not involve a prostaglandin or ATPsensitive $\mathrm{K}^{+}$channel activation because the vasodilation is not affected by indomethacin or glybenclamide, respectively. A reason for not finding a ET-1 vasodilation in lamb pulmonary resistance arteries could be that the target for the peptide is located in a segment of the vasculature that is technically not accessible. However, this would imply the presence of functionally distinct regions in the resistance circulation, and this possibility appears far-fetched. Interestingly, the dilator response to ET-1 is more marked in the 1day-old as opposed to the 7-day-old piglet (Perreault and De Marte 1993).

Like ET-1, big ET-1 has a dual effect in the piglet pulmonary vasculature (Liben et al. 1993), with the dilator response becoming manifest only at the highest concentration $\left(10^{-8} \mathrm{M}\right)$. As expected, big ET-1 is a pure pulmonary constrictor in the fetal lamb (Jones and Abman 1994). Big ET-1 does not act by itself but through the conversion to ET-1, because its constrictor effect is inhibited by phosphoramidon and BQ-123 and the attendant pressor response parallels the increase in blood ET-1 levels. This also implies that the conversion takes place within the vascular district and that there is significant intravascular ECE activity. Lastly, the observation that the 1-day-old differs from the 7-day-old piglet in showing a greater contraction to Big ET-1 and requiring larger doses of the ECE inhibitor for the suppression of the big ET-1 response suggests that ECE may be more active in the early newborn period. 


\section{ET receptors}

ET receptors are extremely abundant in newborn piglet pulmonary vessels (Perreault and Baribeau 1995). The presence of distinct receptors explains the dilator and constrictor responses. ET-1, ET-3, and both $\mathrm{ET}_{\mathrm{B}}$ receptor agonists, BQ3020 and sarafotoxin $6 \mathrm{c}$, cause transient dilatation of pulmonary vessels. The $\mathrm{ET}_{\mathrm{B} 1}$ receptor is likely responsible for the vasodilator effect, because responses to ET-1 and ET-3 are blunted by the $\mathrm{ET}_{\mathrm{B} 1}$ receptor antagonist RES-701-1. Furthermore, the binding affinity of this $\mathrm{ET}_{\mathrm{B} 1}$ receptor $\left(K_{\mathrm{d}} \approx 25-\right.$ $30 \mathrm{pM}$ ) could explain why the dilator response occurs rapidly and at very low concentrations $\left(10^{-12}-10^{-10} \mathrm{M}\right)$. The presence of $\mathrm{ET}_{\mathrm{A}}$ receptors in the newborn piglet pulmonary vessels is confirmed by the fact that the $\mathrm{ET}_{\mathrm{A}}$ receptor antagonist BQ-123 inhibits significantly the vasoconstrictor response to ET- 1 and is also able to displace $\left[{ }^{125} \mathrm{I}\right] \mathrm{ET}-1$ binding. However, BQ-123 does not inhibit completely the ET-1 constriction, nor does it displace in full the $\left[{ }^{125} \mathrm{I}\right] \mathrm{ET}-1$ binding. This may signify that the peptide binds to more than one receptor subtype for its vasoconstrictor effect and, the presence of $\mathrm{ET}_{\mathrm{B} 2}$ receptors with constrictor properties is certainly plausible. The affinity for ET- 1 is higher in veins than arteries despite the comparable number of binding sites in the two vascular beds. From this, one would expect a greater response to ET-1 in the veins. In fact, it has been reported that ET-1 elicits a greater contraction in resistance veins than arteries of the fetal lamb (Wang and Coceani 1992). Thus, it appears that ET receptors in piglet and lamb pulmonary arteries are predominantly of the $\mathrm{ET}_{\mathrm{A}}$ subtype, similar to what is reported in humans (Fukuroda et al. 1994). Both animal species, then, afford preparations that are a good model of the human pulmonary circulation.

\section{ET-1 in neonatal pulmonary hypertension}

Acute hypoxia does not affect the release of ET-1 in isolated perfused piglet lung (Perreault et al. 1993), but it promotes this release in the conscious newborn lamb (Coe et al. 2002). However, circulating ET-1 levels are increased in the piglet when exposed to chronic hypoxia (14 days) (Perreault et al. 2001). The rise in blood ET-1 can be explained by the fact that hypoxia stimulates ET-1 gene and protein expression (Ivy et al. 1998). Furthermore, chronic hypoxia induces ET receptor changes in the newborn piglet (Gosselin et al. 1997), specifically a decrease of $\mathrm{ET}_{\mathrm{B}}$ receptors, after only 3 days of hypoxia. This reduction in the clearance receptors well accounts for the elevation in circulating ET-1. Significantly, this change in the $\mathrm{ET}_{\mathrm{B}}$ receptors coincides with a decrease in the ET-1 dilator response. It is known that, in the piglet, the pulmonary dilator response to ET-1 entails binding to the $\mathrm{ET}_{\mathrm{B}}$ receptors and is mediated by the release of NO. NO stimulates the soluble form of guanylate cyclase, and the attendant formation of cGMP leads to smooth muscle cell relaxation. Thus, the lesser vasodilatation to ET-1 observed in hypoxic piglets after 3 days may result from several events occurring singly or in combination (i.e., changes in NO formation, in guanylate cyclase activation, or in smooth muscle cell sensitivity to NO). A reduction in the number of $\mathrm{ET}_{\mathrm{B}}$ receptors is also possible and, in fact, there is in the piglet a correlation between the number of $\mathrm{ET}_{\mathrm{B}}$ receptors and the magnitude of the vasodilator response. Conversely, the ET-1 constriction remains stable even though the number of $\mathrm{ET}_{\mathrm{A}}$ receptors falls after 14 days of hypoxia. Increased affinity of those receptors can account, at least in part, for the persistence of the vasoconstrictor response to ET-1 in hypoxia, despite the decrease in the number of receptors. An alternative explanation is that receptors are not decreased but simply are less amenable to occupancy by endogenous ET-1. In fact, it is well known that the binding of ET-1 to its receptor is very firm and that half-life dissociation values vary from 40 to $200 \mathrm{~h}$ (Frelin and Guedin 1994). Whatever the sequence of events, ET-1 receptor occupancy may lead not only to changes in tone but also to vascular remodeling.

\section{Role of ET-1 inhibition in neonatal pulmonary hypertension}

If $\mathrm{ET}_{\mathrm{A}}$ receptors are in fact involved in the hemodynamic and morphologic changes seen in hypoxia-induced pulmonary hypertension, then treatment with an $\mathrm{ET}_{\mathrm{A}}$ receptor antagonist should prevent or reverse these effects. Experiments carried out in chronically instrumented conscious newborn lambs with the $\mathrm{ET}_{\mathrm{A}}$ receptor antagonists PD180988 and PD156707 showed that these antagonists are potent inhibitors of pulmonary vasoconstriction resulting from acute hypoxia $\left(\mathrm{FiO}_{2} \quad 0.10-0.12\right.$ for $\left.1 \mathrm{~h}\right)$ without causing systemic hypotension (Coe et al. 2002). Similarly, in the neonatal piglet model treatment with the $\mathrm{ET}_{\mathrm{A}}$ receptor antagonist TBC3711 reverses a sustained pulmonary hypertension from chronic hypoxia $\left(\mathrm{FiO}_{2}\right.$ 0.10) (Perreault et al. 2001). Specifically, once pulmonary hypertension is established after 3 days of exposure to hypoxia, as evidenced by the increase in right over left ventricle ratio $(0.71 \pm 0.09$ vs. $0.35 \pm 0.01$ for normoxia), pulmonary artery pressure $(24.0 \pm 1.3$ vs. $14.2 \pm 3.4 \mathrm{mmHg}$ for normoxia), and percentage wall thickness of $0-30 \mu \mathrm{m}$ vessels $(26.6 \pm 5.9$ vs. $18.7 \pm 2.4 \%$ for normoxia), treatment with TBC3711 causes a significant reversal of all such changes (Fig. 4). These findings provide strong evidence that, in the neonate, endogenous ET-1, through its binding to the $\mathrm{ET}_{\mathrm{A}}$ receptor, is a major mediator of the sustained pulmonary hypertension and pulmonary vascular remodeling seen in chronic hypoxia. Conversely, in normoxia, interaction of ET-1 with the $\mathrm{ET}_{\mathrm{A}}$ receptor does not appear to play any crucial role in the maintenance of postnatal vascular tone (Coe et al. 2000; Perreault et al. 2001), as oppose to the fetal period (Ivy et al. 1996). An additional interesting observation is that the dilator response to the NO donor SIN-1, after being abolished by exposure to chronic hypoxia, is restored upon treatment with TBC3711 (Fig. 5). The same $\mathrm{ET}_{\mathrm{A}}$ antagonist also reverses the fall in exhaled NO concentration caused by prolonged hypoxia. One could argue that this improved dilator function simply reflects the subsidence of structural alterations. However, considering the greater yield in exhaled NO, it is equally feasible that the antagonist ameliorates cellular function. Other investigators have also provided evidence that ET-1 antagonist treatment of adult rats with monocrotalineinduced pulmonary hypertension enhances both endotheliumdependent and -independent vasodilatation to NO (Prié et al. 1998) and corrects endothelial dysfunction (Prié et al. 1997). If confirmed, the latter findings point to an additional important role for ET-1 in neonatal pulmonary vasoregulation. 
Fig. 4. Effect of TBC3711 (11 mg/kg per dose, twice a day) on pulmonary arterial wall thickness $(\%$ wall thickness $=(($ external diameter - internal diameter)/external diameter $) \times 100)$ of different vessel size $(0-30,30-60,60-90,90-120$, and $>120 \mu \mathrm{m})$ in newborn piglets exposed for 14 days to normoxia or hypoxia $\left(10 \% \mathrm{O}_{2}\right)$. Values are means $\pm \mathrm{SD} . *, P<0.001$ compared with normoxic control group; $\dagger, P<0.001$ compared with hypoxic control group; $\ddagger, P<0.01$ compared with hypoxic control group. Reproduced from Perreault et al. (2001) with kind permission from Lippincott Williams \& Wilkins.

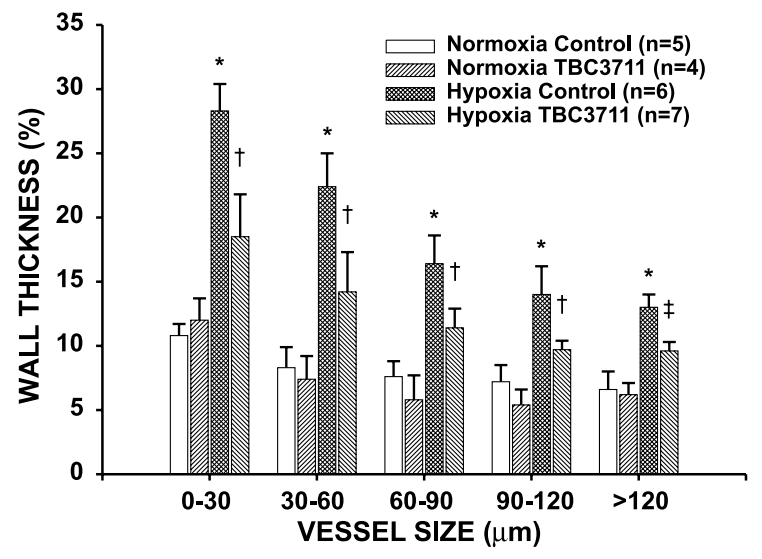

Fig. 5. Vasodilator response to SIN-1 in isolated perfused lungs of newborn piglets exposed to normoxia or hypoxia for 14 days with or without treatment with TBC3711 $(11 \mathrm{mg} / \mathrm{kg}$ per dose, twice a day). Responses are the lowest perfusion pressure reached for each concentration tested. Values are means \pm SD. $\mathrm{B}$, baseline perfusion pressure; $\mathrm{RB}$, baseline perfusion pressure raised by the addition of the endoperoxide analogue U-46619. Reproduced from Perreault et al. (2001) with kind permission from Lippincott Williams \& Wilkins.

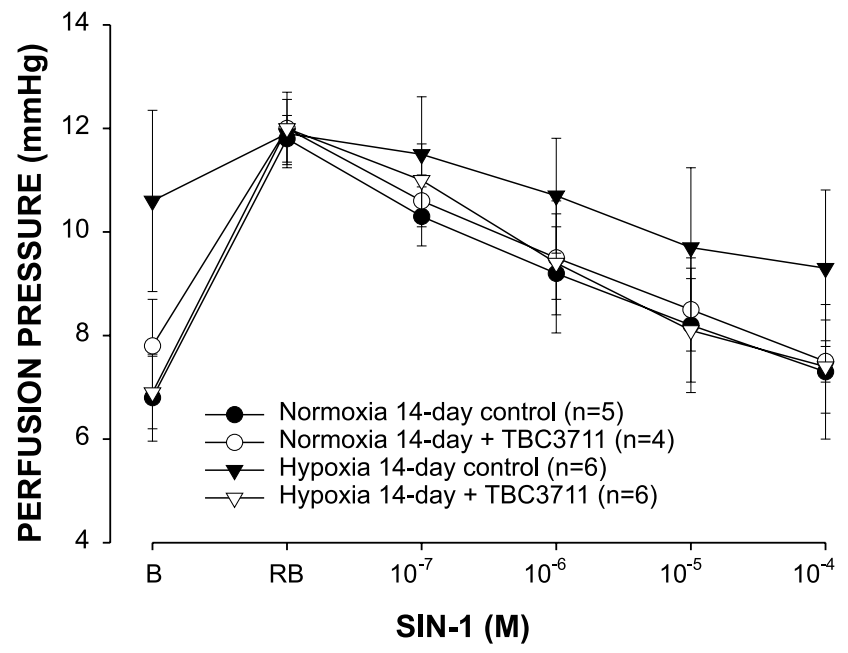

In hypoxia, ET-1 circulating levels are increased by treatment with the $\mathrm{ET}_{\mathrm{A}}$ receptor antagonist $\mathrm{TBC} 3711$. This could suggest that the antagonist binds to $\mathrm{ET}_{\mathrm{B}}$ receptors, hence interfering with ET-1 clearance, or that it affects the synthesis and (or) release of the peptide. A nonspecific binding to $\mathrm{ET}_{\mathrm{B}}$ receptors is unlikely, because TBC3711 is highly specific for the $\mathrm{ET}_{\mathrm{A}}$ receptors with a selectivity exceeding that reported for BQ-123 (Ihara et al. 1992). PD180988 does not affect significantly the systemic circulation in the conscious newborn lamb (Coe et al. 2000). On the other hand, in the intact anesthetized animals, TBC3711 reduces systemic vascular resistance without causing significant hypotension as cardiac output is, in fact, increased. As expected, hemoglobin concentration is increased in hypoxia, but it fails to increase in hypoxic animals treated with TBC3711. The reason for the latter finding is unclear. However, it has been suggested that both ET-1 and erythropoietin gene expression are stimulated by hypoxia and hypoperfusion (Ratcliffe et al. 1990; Ritthaler et al. 1996). Therefore, improving renal perfusion through $\mathrm{ET}_{\mathrm{A}}$ receptor blockade may reduce erythropoietin expression and, consequently, hemoglobin.

Of interest, an ECE-neutral endopeptidase inhibitor (NEP), CGS 26303, has been evaluated in another model of pulmonary hypertension (i.e., the hypertension associated with congenital diaphragmatic hernia $(\mathrm{CDH})$ ) (Kavanagh et al. 2000). $\mathrm{CDH}$ was induced in fetal pups by exposing the dam to nitrofen. Newborn rats from mothers subsequently treated with CGS 26303 have an increased survival and a reduced severity of pulmonary hypoplasia compared with the untreated newborns. The authors conclude that blockade of the ET system attenuates the degree of pulmonary hypoplasia. Consistent with this conclusion are also the results of a recent study in which an ET-1 antagonist proved to be beneficial in an experimental model of congenital diaphragmatic hernia in the lamb (Thebaud et al. 2000). Equally significant is the fact that ET-1 antagonists reverse the pulmonary hypertension consequent to increased blood flow (Petrossian et al. 1999) or discontinuation of NO inhalation (McMullan et al. 2001). Collectively, these data strongly support the role of ET-1 in the pathogenesis of pulmonary hypertension. Because of their effects on pulmonary vascular structure and hemodynamics, $\mathrm{ET}_{\mathrm{A}}$ receptor antagonists, and possibly ECE-NEP inhibitors, lend themselves to therapeutic use in the hypertensive infant.

Chronic neonatal lung injury, or bronchopulmonary dysplasia (BPD), remains an important cause of morbidity and mortality in preterm infants requiring respiratory support with mechanical ventilation and prolonged use of supplemental oxygen (Edwards et al. 1977). Pulmonary hypertension is a common complication in infants with established BPD and is an important adverse factor in their outcome. It was hypothesized that hyperoxia leads to lung injury, pulmonary vascular abnormalities, and ET-1 upregulation, through the production of reactive oxygen species with the attendant peroxidation of membrane lipids and the release of reactive products such as lipid hydroperoxides and 8-isoprostane. Prepro-ET-1 mRNA expression in air-exposed neonatal rats declines significantly after birth and remains low (Jankov et al. 2000), while, in contrast, it is significantly increased in animals exposed to $60 \%$ oxygen. Rat pups treated with the antioxidant U74389G have no evidence of the oxygenmediated increase in prepro-ET-1 mRNA expression (Fig. 6). Measurement of ET-1 protein content by immunohistochemistry accords with this action of U74389G. In addition, right ventricular hypertrophy, as an index of pulmonary hypertension, is completely reversed in animals treated with U74389G. Likewise, lipid hydroperoxide formation in lung tissue, as assessed by measurement of lung 8isoprostane content, is attenuated by the same treatment. Of 
Fig. 6. Effect of U74389G on total lung prepro-ET-1 mRNA. (A) Whole lung prepro-ET-1 mRNA after exposure to air or $60 \%$ $\mathrm{O}_{2}$ for $14 \mathrm{~d}$. Newborn rats received daily i.p. injections of $10 \mathrm{mg} / \mathrm{kg}$ U74389 in CS-4 vehicle (U74389G), CS-4 vehicle alone (vehicle), or no intervention (untreated). Bars represent means \pm SE for four litters. ${ }^{*}, P<0.05$, by one-way ANOVA, for animals exposed to $60 \% \mathrm{O}_{2}$ compared with those in air in the same treatment group; \#, $P<0.05$, by one-way ANOVA, for U74389G-treated animals compared with untreated or vehicletreated animals exposed to $60 \% \mathrm{O}_{2}$. (B) Northern blot analysis of whole lung prepro-ET-1 mRNA at birth (day 0) and after exposure to air $(\mathrm{A})$ or $60 \% \mathrm{O}_{2}(\mathrm{O})$ for $14 \mathrm{~d}$. Newborn rats received either no injections (untreated) or daily i.p. injections of either

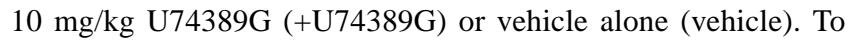
correct for differences in loading of RNA and transfer to membranes, all results were normalized to GAPDH mRNA. Transcript sizes are in kb. Reproduced from Jankov et al. (2000) with kind permission from Lippincott Williams \& Wilkins.

A

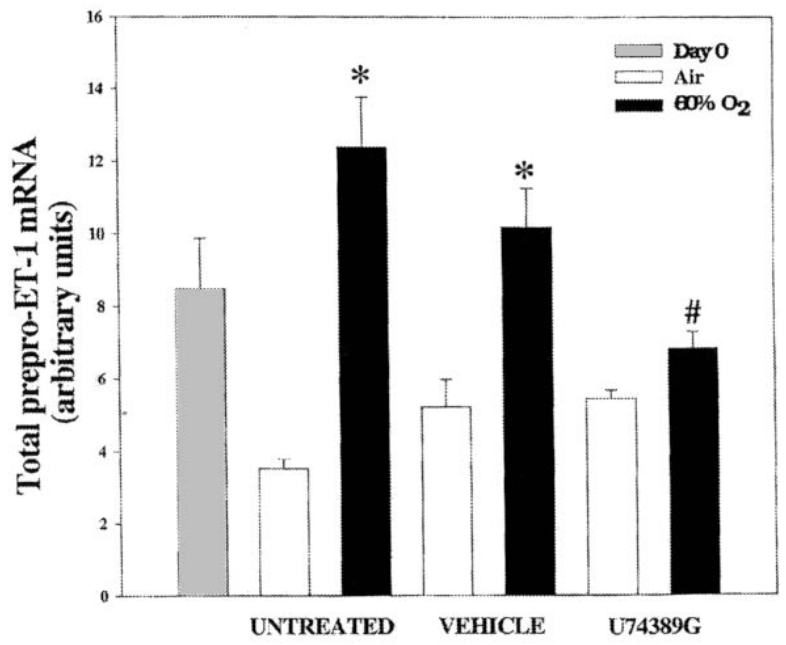

B

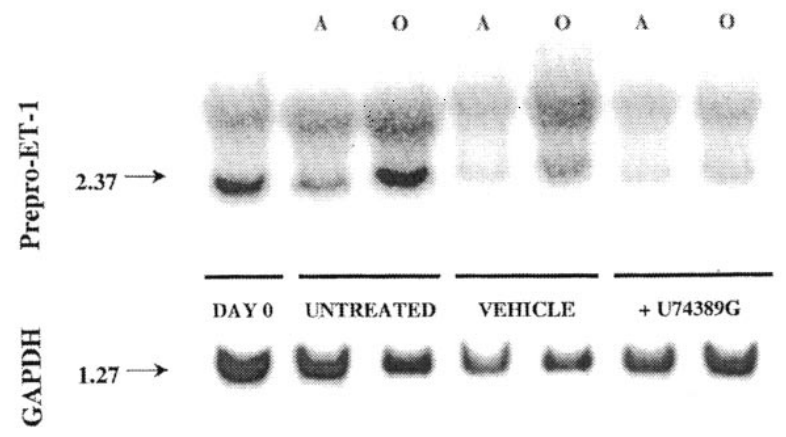

interest, 8-isoprostane causes a significant increase in prepro-ET-1 mRNA expression in fetal lung cells. When treated with the dual ET-1 receptor antagonist SB217242, neonatal pups do not develop oxygen-linked right ventricular hypertrophy, nor do they show an increase in perivascular smooth muscle mass (Fig. 7) (Jankov et al. 2001). The foregoing data suggest that the increase in ET-1 observed with exposure to $60 \%$ oxygen is causally related to the development of pulmonary hypertension and that there could be a direct link between formation of products of lipid
Fig. 7. Effect of the mixed endothelin receptor antagonist SB217242 on $60 \%-\mathrm{O}_{2}$-mediated right ventricular hypertrophy (RVH). RV dry weight compared with that of the combined left ventricle and septum $(\mathrm{LV}+\mathrm{S})$, as an index of RVH, after exposure to air or $60 \% \mathrm{O}_{2}$ for 14 days. Newborn rats received daily i.p. injections of SB217242 (5 mg/kg) in $0.9 \%$ saline vehicle or $0.9 \%$ saline vehicle alone. The injection of SB217242 attenuated the $60 \% \mathrm{O}_{2}$-mediated increase in $\mathrm{RVH}$. Plot points represent means \pm SE for four litters. *, $P<0.05$, by one-way ANOVA, for vehicle-treated animals exposed to $60 \% \mathrm{O}_{2}$ compared with those in air; \#, $P<0.05$, by one-way ANOVA, for SB217242treated animals compared with vehicle-treated animals exposed to $60 \% \mathrm{O}_{2}$. Reproduced from Jankov et al. (2001) with kind permission from Lippincott Williams \& Wilkins.

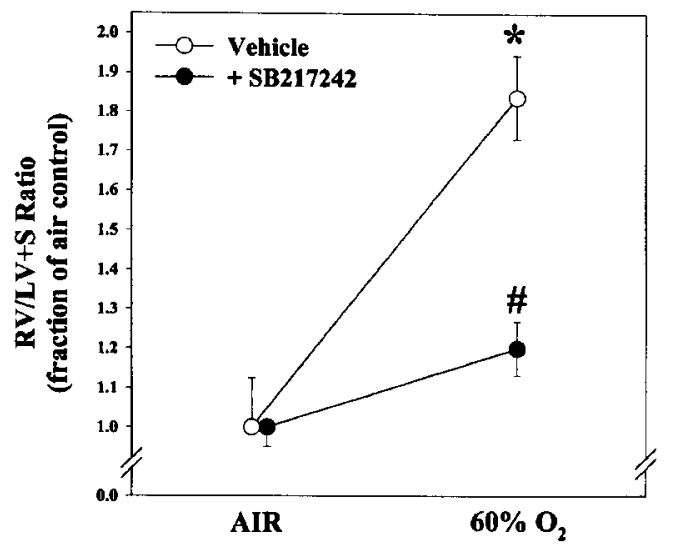

peroxidation and expression of ET-1 after birth. Undoubtedly, this finding has implications for the clinic.

\section{Conclusion}

Studies to date point to an important role of ET-1 in the normal and diseased vasculature during the perinatal period. Specifically, there is strong evidence that ET-1 is an effector agent for oxygen in the ductus arteriosus and that it plays a critical role in the closure of the vessel at birth. Furthermore, ET-1 appears to be a causative agent in the pathogenesis of hypoxia- or hyperoxia-induced pulmonary hypertensive state. Findings are amenable to practical applications in the management of infants with pulmonary hypertension or requiring persistent patency of the ductus arteriosus.

\section{Acknowledgements}

Studies of the authors were supported by the Medical Research Council of Canada (MT-12973) (T.P.), La Foundation du Québec des maladies du coeur (T.P.), and the Heart and Stroke Foundation of Ontario (T-3329) (F.C.). The nature of this publication has imposed limitations on the bibliography. We apologize to the many authors whose work was not cited.

\section{References}

Adamson, S.L., Whiteley, K.J., and Langille, B.L. 1996. Endothelin1 constricts fetoplacental microcirculation and decreases fetal $\mathrm{O}_{2}$ consumption in sheep. Am. J. Physiol. 270: H16-H23. 
Adeagbo, A.S.O., Coceani, F., and Olley, P.M. 1982. The response of the lamb ductus venosus to prostaglandins and inhibitors of prostaglandin and thromboxane synthesis. Circ. Res. 51: 580586.

Adeagbo, A.S.O., Bishai, I., Lees, J., Olley, P.M., and Coceani, F. 1985. Evidence for a role of prostaglandin $I_{2}$ and thromboxane $A_{2}$ in the ductus venosus of the lamb. Can. J. Physiol. Pharmacol. 63: 1101-1105.

Adeagbo, A.S.O., Breen, C.A., Cutz, E., Lees, J.G., Olley, P.M., and Coceani, F. 1990. Lamb ductus venosus: evidence of a cytochrome P-450 mechanism in its contractile tension. J. Pharmacol. Exp. Ther. 252: 875-879.

Aranda, J.V., Monin, P., Beharry, K., Bairam, A., and Vert, P. 1992. The effect of endothelin-1 on the cerebrovascular response to hypoxia and hypercapnia in the newborn. Semin. Perinatol. 16: 196-199.

Block, B.S.B., Llanos, A.J., and Creasey, R.K. 1984. Responses of the growth retarded fetus to acute hypoxemia and acidemia in fetal lambs. Am. J. Obstet. Gynecol. 120: 817-824.

Cheung, C.Y. 1994. Regulation of atrial natriuretic factor release by endothelin in ovine fetuses. Am. J. Physiol. 267: R380-R386.

Coceani, F. 1994. Control of the ductus arteriosus - a new function for cytochrome P450, endothelin and nitric oxide. Biochem. Pharmacol. 48: 1315-1318.

Coceani, F., and Kelsey, L. 1991. Endothelin-1 release from lamb ductus arteriosus: relevance to postnatal closure of the vessel. Can. J. Physiol. Pharmacol. 69: 218-221.

Coceani, F., and Kelsey, L. 2000. Endothelin-1 release from the lamb ductus arteriosus: are carbon monoxide and nitric oxide regulatory agents? Life Sci. 66: 2613-2623.

Coceani, F., Armstrong, C., and Kelsey, L. 1989. Endothelin is a potent constrictor of the lamb ductus arteriosus. Can. J. Physiol. Pharmacol. 67: 902-904.

Coceani, F., Kelsey, L., and Seidlitz, E. 1992. Evidence for an effector role of endothelin in closure of the ductus arteriosus at birth. Can. J. Physiol. Pharmacol. 70: 1061-1064.

Coceani, F., Kelsey, L., and Seidlitz, E. 1996a. Carbon monoxide induced relaxation of the ductus arteriosus in the lamb: evidence against the prime role of guanylyl cyclase. Br. J. Pharmacol. 118: $1689-1696$.

Coceani, F., Kelsey, L., Seidlitz, E, and Korzekwa, K. 1996b. Inhibition of the contraction of the ductus arteriosus to oxygen by 1aminobenzotriazole, a mechanism-based inactivator of cytochrome P450. Br. J. Pharmacol. 117: 1586-1592.

Coceani, F., Liu, Y., Seidlitz, E., Kelsey, L., Kuwaki, T., Ackerley, C., and Yanagisawa, M. 1999. Endothelin A receptor is necessary for $\mathrm{O}_{2}$ constriction but not closure of ductus arteriosus. Am. J. Physiol. 277: H1521-H1531.

Coe, Y., Haleen, S.J., Welch, K.M., Liu, Y.-A., and Coceani, F. 2002. The endothelin A receptor antagonists PD 156707 (CI1020) and PD 180988 (CI-1034) reverse the hypoxic pulmonary vasoconstriction in the perinatal lamb. J. Pharmacol. Exp. Ther. 302: $672-680$.

Edwards, D.K., Dyer, W.M., and Northway, W.H. 1977. Twelve years' experience with bronchopulmonary dysplasia. Pediatrics, 59: 839-846.

Frelin, C., and Guedin, D. 1994. Why are circulating concentrations of endothelin-1 so low? Cardiovasc. Res. 28: 1613-1622.

Fukuroda, T., Kobayashi, M., Ozaki, S., Yano, M., Miyauchi, T., Onizuka, M., Sugishita, Y., Goto, K., and Nishikibe, M. 1994. Endothelin receptor subtypes in human versus rabbit pulmonary arteries. J. Appl. Physiol. 76: 1976-1982.

Gosselin, R., Gutkowska, J., Baribeau, J., and Perreault, T. 1997.
Endothelin receptor changes in hypoxia-induced pulmonary hypertension in the newborn piglet. Am. J. Physiol. 273: L72-L79.

Ihara, M., Noguchi, K., Saeki, T., Fukuroda, T., Tsuchida, S., Kimura, S., Fukami, T., Ishikawa, K., Nishikibe, M., and Yano, M. 1992. Biological profiles of highly potent novel endothelin antagonists selective for the $\mathrm{ET}_{\mathrm{A}}$ receptor. Life Sci. 50: 247-255.

Ivy, D.D., Kinsella, J.P., and Abman, A.H. 1996. Endothelin blockade augments pulmonary vasodilation in the ovine fetus. J. Appl. Physiol. 81: 2481-2487.

Ivy, D.D., Le Cras, T.D., Horan, M.P., and Abman, S.H. 1998. Increased lung preproET-1 and decreased $\mathrm{ET}_{\mathrm{B}}$-receptor gene expression in fetal pulmonary hypertension. Am. J. Physiol. 274: L535-L541.

Jankov, R.P., Luo, X., Cabacungan, J., Belcastro, R., Frndova, H., Lye, S.J., and Tanswell, A.K. 2000. Endothelin-1 and $\mathrm{O}_{2}$-mediated pulmonary hypertension in neonatal rats: a role for products of lipid peroxidation. Pediatr. Res. 48: 289-298.

Jankov, R.P., Luo, X., Belcastro, R., Copland, I., Frndova, H., Lye, S.J., Hoidal, J.R., Post, M., and Tanswell, A.K. 2001. Gadolinium chloride inhibits pulmonary macrophage influx and prevents $\mathrm{O}_{2}$-induced pulmonary hypertension in the neonatal rat. Pediatr. Res. 50: 172-183.

Jones, O.W., III, and Abman, S.H. 1994. Systemic and pulmonary hemodynamic effects of big endothelin-1 and phosphoramidon in the ovine fetus. Am. J. Physiol. 266: R929-R955.

Kavanagh, M., Battistini, B., Kluth, D., Jean, S., Fournier, L., Jeng, A.Y., Major, D., and Cloutier, R. 2000. Effect of CGS 26303, an endothelin-converting enzyme-neutral endopeptidase inhibitor, on nitrofen-induced congenital diaphragmatic hernia in the rat. J. Pediatr. Surg. 35: 780-784.

Kiserud, T., Ozaki, T., Nishina, H., Rodeck, C., and Hanson, M.A. 2000. Effect of NO, phenylephrine, and hypoxemia on ductus venosus diameter in fetal sheep. Am. J. Physiol. 279: H1166H1171.

Liben, S., Stewart, D.J., De Marte, J., and Perreault, T. 1993. Ontogeny of Big endothelin-1 effects in newborn piglet pulmonary vasculature. Am. J. Physiol. 265: H139-H145.

Liu, Y.A., Theis, J.G., and Coceani, F. 2000. Contractile and relaxing mechanisms in pulmonary resistance arteries of the preterm fetal lamb. Biol. Neonate, 77: 253-260.

McLarnon, J.G., Wang, X., Bae, J.H., and Kim, S.U. 1999. Endothelin-induced changes in intracellular calcium in human microglia. Neurosci. Lett. 263: 9-12.

McMullan, D.M., Bekker, J.M., Johengen, M.J., Hendricks-Munoz, K., Gerrets, R., Black, S.M., and Fineman, J.R. 2001. Inhaled nitric oxide-induced rebound pulmonary hypertension: role for endothelin-1. Am. J. Physiol. 280: H777-H785.

Moor, A.N., Murtazina, R., and Fliegel, L. 2000. Calcium and osmotic regulation of the $\mathrm{Na}^{+} / \mathrm{H}^{+}$exchanger in neonatal ventricular myocytes. J. Mol. Cell Cardiol. 32: 925-936.

Nankervis, C.A., and Novicki, P.T. 2000. Role of endothelin-1 in regulation of the postnatal intestinal circulation. Am. J. Physiol. 278: G367-G375.

Nankervis, C.A., Dunaway, D.J., and Miller, C.E. 2001. Endothelin $\mathrm{ET}_{\mathrm{A}}$ and $\mathrm{ET}_{\mathrm{B}}$ receptors in postnatal intestine. Am. J. Physiol. 280: G555-G562.

Perreault, T., and Baribeau, J. 1995. Characterization of endothelin receptors in newborn piglet lung. Am. J. Physiol. 268: L607L614.

Perreault, T., and De Marte, J. 1991. Endothelin-1 has a dilator effect on neonatal pig pulmonary vasculature. J. Cardiovasc. Pharmacol. 18: $43-50$.

Perreault, T., and De Marte, J. 1993. Maturational changes in endo- 
thelium-derived relaxations in newborn piglet pulmonary circulation. Am. J. Physiol. 264: H302-H309.

Perreault, T., Stewart, D.J., Cernacek, P., Wu, X., Ni, F., De Marte, J., and Giaid, A. 1993. Newborn piglet lungs release endothelin-1: effect of alpha-thrombin and hypoxia. Can. J. Physiol. Pharmacol. 71: 227-33.

Perreault, T., Berkenbosch, J.W., Barrington, K.J., Decker, E.R., Wu, C., Brock, T.A., and Baribeau, J. 2001. TBC3711, an $\mathrm{ET}_{\mathrm{A}}$ receptor antagonist, reduces neonatal hypoxia-induced pulmonary hypertension in piglets. Pediatr. Res. 50: 374-383.

Petrossian, E., Parry, A.J., Reddy, V.M., Akkersdijk, G.P., McMullan, M., LeNardo Thompson, L., Hendricks-Munoz, K.D., Hallak, H., Hanley, F.L., and Fineman, J.R. 1999. Endothelin receptor blockade prevents the rise in pulmonary vascular resistance after cardiopulmonary bypass in lambs with increased blood flow. J. Thorac. Cardiovasc. Surg. 117: 314-323.

Prié, S., Leung, T.K., Cernacek, P., Ryan, J.W., and Dupuis, J. 1997. The orally active $\mathrm{ET}_{\mathrm{A}}$ receptor antagonist (+)-(S)-2(4,6dimethoxy-pyridin-2-yloxy)-3-methoxy-3,3-diphenyl-propionic acid (LU 135252) prevents the development of pulmonary hypertension and endothelial metabolic dysfunction in monocrotalinetreated rats. J. Pharmacol. Exp. Ther. 282: 1312-1318.

Prié, S., Stewart, D.J., and Dupuis, J. 1998. Endothelin A receptor blockade improves nitric oxide-mediated vasodilation in monocrotaline-induced pulmonary hypertension. Circulation, 97: 2169-2174.

Pryds, O., Greisen, G., Lou, H., and Friis-Hansen, B. 1990. Vasoparalysis associated with brain damage in asphyxiated term infants. J. Pediatr. 117: 119-125.

Rakugi, H., Tabuchi, Y., Nakamaru, M., Nagano, M., Higashimori, K., Mikami, T., Ogihara, T., and Suzuki, N. 1990. Evidence for endothelin-1 release from resistance vessels of rates in response to hypoxia. Biochem. Biophys. Res. Commun. 169: 973-977.

Ratcliffe, P.J., Jones, R.W., Philipps, R.E., Nicholls, L.G., and Bell, J.I. 1990. Oxygen-dependent modulation of erythropoietin mRNA levels. J. Exp. Med. 172: 657-660.

Reeve, H.L., Tolarova, S., Nelson, D.P., Archer, S., and Weir, E.K. 2001. Redox control of oxygen sensing in the rabbit ductus arteriosus. J. Physiol. 533: 253-261.

Reilly, F.D., and Russell, P.T. 1977. Neurohistochemical evidence supporting an absence of adrenergic and cholinergic innervation in the human placenta and umbilical cord. Anat. Rec. 188: 277-286.
Ritthaler, T., Gopfert, T., Firth, J.D., Ratcliffe, P.J., Kramer, B.K., and Kurtz, A. 1996. Influence of hypoxia on hepatic and renal endothelin gene expression. Pflugers Arch. 431: 587-593.

Taniguchi, T., Azuma, H., Okada, Y., Naiki, H., Hollenberg, M.D., and Muramatsu, I. 2001. Endothelin-1-endothelin receptor type A mediates closure of the rat ductus arteriosus at birth. J. Physiol. 537: 579-585.

Thebaud, B., De Lagausie, P., Forgues, D., Aigrain, Y., Mercier,

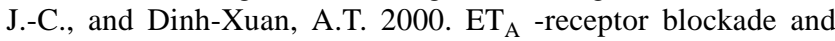
$\mathrm{ET}_{\mathrm{B}}$-receptor stimulation in experimental congenital diaphragmatic hernia, Am. J. Physiol. 278: L923-L932.

Touyz, R.M., Fareh, J., Thibault, G., Larivière, R., and Schiffrin, E.L. 1995. Modulation of $\mathrm{Ca}^{2+}$ transients in neonatal and adult rat cardiomyocytes by endothelin-1. J. Cardiovasc. Pharmacol. 26: S297-S299.

Wang, Y., and Coceani, F. 1992. Isolated pulmonary resistance vessels from fetal lambs. Contractile behavior and responses to indomethacin and endothelin-1. Circ. Res. 71: 320-330.

Wang, Y., Mercer-Connolly, A., Lines, L., Toyoda, O., and Coceani, F. 1994. Endothelium-denuded pulmonary resistance arteries from the fetal lamb: preparation and response to vasoactive agents. J. Pharmacol. Toxicol. Methods, 32: 85-91.

Weir, F.J., Ohlsson, A., Fong, K., Amankwah, K., and Coceani, F. 1999. Does endothelin-1 reduce superior mesenteric artery blood flow velocity in preterm neonates? Arch. Dis. Child. Fetal Neonatal Ed. 80: F123-F127.

Xu, Y., Hopfner, R.L., McNeill, J.R., and Gopalakrishnan, V. 1999. Vasopressin accelerates protein synthesis in neonatal rat cardiomyocytes. Mol. Cell Biochem. 195: 183-190.

Yakubu, M.A., and Leffler, C.W. 1999. Regulation of ET-1 biosynthesis in cerebral microvascular endothelial cells by vasoactive agents and PKC. Am. J. Physiol. 276: C300-C305.

Yakubu, M.A., and Leffler, C.W. 2000. Enhanced pial arteriolar sensivity to bioactive agents following exposure to endothelin-1. Life Sci. 66: 307-316.

Yanagisawa, M., Kurihara, H., Kimura, S., Tomobe, Y., Kobayashi, M., Mitsui, Y., Yazaki, Y., Goto, K., and Masaki, T. 1988. A novel potent vasoconstrictor peptide produced by vascular endothelial cells. Nature (London), 332: 411-415. 